\title{
Mobile Game Education About using Capitals Hiragana and Katakana Fisher-Yates Shuffle Algorithm and Fuzzy Tsukamoto
}

\author{
Rahmiati, Rika Melyanti, Des Suryani, Ambiyar
}

\begin{abstract}
Japanese is a different language because it uses the letters Katakana and Hiragana. Japanese learning at the Kansai Vocational School Pekanbaru encountered several obstacles including the lack of learning facilities and a learning atmosphere that tends to be boring so that many students have difficulty learning and choosing to play games. Educational games on mobile devices are a new learning method that is considered to be more attractive to someone to learn. Fisher-Yates is a randomization technique on questions so questions that come out will be different and can be generated without repetition and duplication. Fuzzy Tsukamoto is a method used in decision-making to determine the score at the end of the quiz. From this research, it can be found that Fisher-Yates can determine the randomization solution that is not multiple and varied object randomization. Fuzzy Tsukamoto has a fairly good accuracy between calculations based on the system and calculations manually, although it does not show results that are $100 \%$ the same in each calculation. Educational game recognizing the letters Katakana and Hiragana is expected to help students overcome difficulties in understanding and learning Japanese related to the mastery of the letters Katakana and Hiragana.
\end{abstract}

Keywords: Mobile Game, FYS, Fuzzy Tsukamoto.

\section{INTRODUCTION}

$\mathrm{T}_{\mathrm{e}}$ human interests, it cannot be denied that the technological developments that occur at this time are very rapid. Especially with technological developments in the field of games. [1] add games allow users to sharpen their brains, exercise patience, build a positive spirit, and much more. Japanese is a language that is different from other languages because it is written using hiragana and katakana letters.

SMK Kansai Pekanbaru is a vocational high school in Pekanbaru that uses three languages as the language of learning, one of which is Japanese and is one of the reference

Manuscript received on May 20, 2021.

Revised Manuscript received on May 25, 2021.

Manuscript published on May 30, 2021.

* Correspondence Author

Rahmiati*, Doctoral student of Technology and Vocational Education, Universitas Negeri Padang - Indonesia and Lecturer of STMIK Amik Riau Indonesia. Email: rahmiati@sar.ac.id

Rika Melyanti, Doctoral Student of Technology and Vocational Education, Universitas Negeri Padang - Indonesia and Lecturer of STMIK Hang Tuah Pekanbaru - Indonesia. Email: camelya2105@htp.ac.id

Des Suryani, Doctoral Student of Technology and Vocational Education, Universitas Negeri Padang - Indonesia and Lecturer of UIR Riau - Indonesia. Email: des.suryani@eng.uir.ac.id

Ambiyar, Senior lecturers/professors of Technology and Vocational Education, Universitas Negeri Padang-Indonesia: ambiyar@ft.unp.ac.id

(C) The Authors. Published by Blue Eyes Intelligence Engineering and Sciences Publication (BEIESP). This is an open access article under the CC BY-NC-ND license (http://creativecommons.org/licenses/by-nc-nd/4.0/) schools in Pekanbaru City, problems that often occur in learning Japanese include the lack of learning facilities and a learning atmosphere that tends to be boring so that most students prefer to play games rather than learn Japanese. Judging from these problems, the solution is to make a game that can be a learning medium for recognizing hiragana and katakana letters using the right method. Several studies have been published related to games that use algorithms Fisher-Yates Shuffle (FYS) and Fuzzy Tsukamoto, among others Implementation of Algorithms FYS and Fuzzy [2].

Tsukamoto In-Game Quiz Guess Sunda Based on Android [3] and Implementation Fisher-Yates Algorithm to Randomize Online Exam Questions for New Student Admissions (Case Study: Riau Lancang Kuning University) [4]. From both, the study authors conclude that algorithms the FYS and Fuzzy Tsukamoto suitable to be applied in educational games hiragana and katakana recognize that provide entertainment while providing media education for android users of the knowledge of the Japanese language right.

\section{SIGNIFICANCE STUDY}

According to [5], the FYS (named after its discoverer, Ronald Fisher, and Frank Yates) was used to change the order of randomly given input. The permutations generated by this algorithm appear with the same probability. The basic method is given to generate permutationsrandom of numbers 1 - N. This algorithm is stated to be normal because the permutations generated by this algorithm appear with the same probability, this is proven by randomizing a set of cards that are repeated. FYS is used to change a randomly assigned input sequence. The permutations generated by this algorithm appear with the same probability. The basic method given to generate a random permutation of numbers 1 - N goes as follows: 1) Write down the numbers from 1 to n; 2) Fill in the $k$ values with random numbers between 0 to I + 1 round down; 3) Count from the low end, replace the $k$ values and write them in place else; 4) Repeat from step 2 until all numbers are replaced; 5) The sequence of numbers written in step 3 is now a random permutation of the original number; and 6) In the new (modern) version the selected numbers are not crossed out, but their positions are exchanged with the last digit of the numbers that have not been selected. Table-I is a working example of the modern version. The range is the number of numbers that have not been selected, a roll is a random number selected, scratch is a list of numbers that have not been selected, the result is the result of the permutation that will be obtained.

Published By:

Blue Eyes Intelligence Engineering \& Sciences Publication

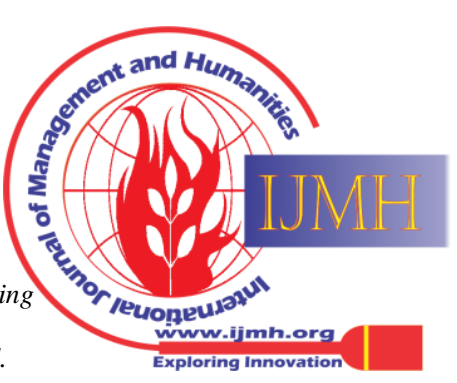


Table- I: Example Calculation of Algorithm Fisher-Yates

\begin{tabular}{|c|c|c|c|}
\hline Range & Roll & Scratch & Result \\
\hline $1-8$ & & 12345678 & \\
\hline $1-7$ & 3 & 1284567 & 3 \\
\hline $1-6$ & 1 & 728456 & 13 \\
\hline $1-5$ & 2 & 72865 & 413 \\
\hline $1-4$ & 4 & 7586 & 2413 \\
\hline $1-3$ & 2 & 758 & 62413 \\
\hline $1-2$ & 1 & 5 & 562413 \\
\hline & & & 7562413 \\
& & & 57562413 \\
\hline
\end{tabular}

Fuzzy Tsukamoto's current technology has entered into one of the human interests, it cannot be denied if the technological developments that occur at this time are very rapid. Especially with technological developments in the field of games. Games allow users to sharpen their brains, exercise patience, build positive morale, and much more. Japanese is a language that is different from other languages because it is written using hiragana and katakana letters.

According to [5], in the Tsukamoto Method, each rule is represented using a fuzzy set, using a monotonous membership function. To be able to determine the crisp output value or the firm result you are looking for is biased by changing the input (in the form of a fuzzy set obtained from the composition of the fuzzy rules) into a number in the fuzzy set domain. This method is called the method of often used in the method of Tsukamoto is method defuzzification an average centered (Center Average Defuzzifier). Several terms need to be known in understanding fuzzy systems, namely: Fuzzy Variables are variables to be discussed in a fuzzy system. Example: Age, Temperature, Demand, Inventory, Production, and so on. Fuzzy Set Suppose that $\mathrm{X}$ is a given universe, there is $\mathrm{A}$ in $\mathrm{X}$ such that: $\mathrm{A}=\{\mathrm{x}, \mu \mathrm{A}[\mathrm{x}] \mid \mathrm{x} \in \mathrm{X}, \mu \mathrm{A}: \mathrm{x} \rightarrow[0,1]\} \mathrm{A}$ fuzzy set $A$ in $X$ is defined as a set characterized by a membership function, which mixes each with a real number in the interval, with the value representing the degree of membership $\mathrm{x}$ in A. A fuzzy set is a group that represents a certain condition or state in a fuzzy variable. Suppose $\mathrm{X}=$ Age is a fuzzy variable. So it can be defined the set of "Young", "Parobaya", and "Old". Universe Talking Universe is all values that are allowed to operate in a fuzzy variable. The speaking universe is a set of real numbers that constantly increases (increases) monotonically from left to right. The value of the universe of speech can be in the form of positive or negative numbers. Sometimes the value of the universe of this conversation is not limited to its upper limit. Example: universe of speech for variable age: $[0,+\infty]$. So that the universe of talk of the variable aegis $0 \leq$ age $<+\infty$. In this case, the permissible operation for the variable age is greater than or equal to 0 , or less than infinitely positive. Domain fuzzy set is the total value allowed in the universe of speech and may be operated in a fuzzy set. As the universe of speech, the domain is a set of real numbers that are constantly increasing (increasing) monotonically from left to right. Domain values can be either positive or negative numbers. Example of fuzzy set domain: Young $=[0.45]$. defuzzification (affirmation). In methods defuzzification is

\section{RESULT AND DISCUSSION}

\section{A. Formulation Gameplay}

The stages of gameplay that are carried out are making a game that has a learning menu and learning quizzes will show the basic hiragana and katakana letters while the quiz will have several levels, namely easy, medium, and hard which have their respective difficulty levels. each and itself will use several methods to regulate the processinteractionThe game is the application of the FYS and Fuzzy Tsukamoto algorithm.

\section{B. Concept of the FYS Algorithm}

The FYS algorithm is an algorithm that can randomize questions, the application of FYS to the questions raised in this game has several advantages, namely:

Note:

Variable Range $(\mathrm{M})=$ number of questions

Variable Roll $(\mathrm{N})=$ random number chosen by the system

Variable Scratch $(\mathrm{X})=$ initial permutation

Variable Result $(\mathrm{Y})=$ the permutation results obtained Problem:

$$
\begin{aligned}
& \mathrm{M}=1-10,1-9,1-8, \ldots, 1-1 \\
& \mathrm{~N}=\mathrm{n} \\
& \mathrm{X}=1,2,3, \ldots, 10
\end{aligned}
$$

Table- II: Answer

\begin{tabular}{|c|c|c|c|}
\hline $\mathbf{M}$ & $\mathbf{N}$ & $\mathbf{X}$ & $\mathbf{Y}$ \\
\hline & & 12345678910 & \\
\hline $1-10$ & 3 & 1210456789 & 3 \\
\hline $1-9$ & 1 & 210456789 & 31 \\
\hline $1-8$ & 4 & 21046789 & 315 \\
\hline $1-7$ & 2 & 246789 & 31510 \\
\hline $1-6$ & 4 & 24689 & 315107 \\
\hline $1-5$ & 2 & 2689 & 3151074 \\
\hline $1-4$ & 3 & 269 & 31510748 \\
\hline $1-3$ & 2 & 29 & 315107486 \\
\hline $1-2$ & 1 & 9 & 3151074862 \\
\hline & & & 31510748629 \\
\hline
\end{tabular}

In the FYS test above, the order in which the questions appear is as follows: $3,1,5,10,7,4,8,6,2,9$.

\section{Fuzzy Tsukamoto concept}

Formulation of gameplay applies fuzzy Tsukamoto in determining game points. The first stage is the formation of fuzzy Logic Sets and the creation of rules, here are the fuzzy sets for membership functions for time, points, and scores.

Tabel -III: Variable Input

\begin{tabular}{|c|c|c|}
\hline Variable & Association of Input Fuzzy & Range \\
\hline Time Working & Quick & $0-20$ \\
\hline & Medium & $10-30$ \\
\hline & Slow & $20-30$ \\
\hline pts & Bit & $0-70$ \\
\hline & Medium & $30-100$ \\
\hline & Lots & $70-100$ \\
\hline
\end{tabular}

Tabel -IV: Variable output

\begin{tabular}{|c|c|c|}
\hline Variables & Association Output Fuzzy & Range \\
\hline Star & Decreases & $0-100$ \\
\hline & Increases & $10-100$ \\
\hline
\end{tabular}

blished By: 
Here are the rules:

Table -V: Composition rules

\begin{tabular}{|c|c|c|c|}
\hline IF & POINTS & TIME & STAR \\
\hline R1 & LITTLE & LATE & REDUCED \\
\hline R2 & LITTLE & WAS & REDUCED \\
\hline R3 & LITTLE & FASTER & REDUCED \\
\hline R4 & LITTLE & LATE & REDUCED \\
\hline R5 & MODERATE & MODERATE & INCREASE \\
\hline R6 & ARE & QUICKLY & INCREASE \\
\hline R7 & LOT OF & SLOW & INCREASE \\
\hline R8 & LOT OF & MODERATE & INCREASE \\
\hline R9 & LOT OF & RAPID & INCREASE \\
\hline
\end{tabular}

Description:

IF R1 LITTLE AND SLOW THEN THEN LESS

IF R2 IS LITTLE AND MEDIED THEN THENIS

IF R3 LITTLE AND FAST THEN THENLESS

ISIF R4 IS MEDIUM AND SLOW THEN THENLESS

ISIF R5 IS ON AND IS THEN ADD

IF R6 IS ON AND FAST THEN BANG

AND THEN BANG AND R7 BANY THEN

IS ADDED IF R9 IS MANY AND FAST TcHEN ADDS

Problem : IF Points $=60$ AND Time 15

Solution :

Points

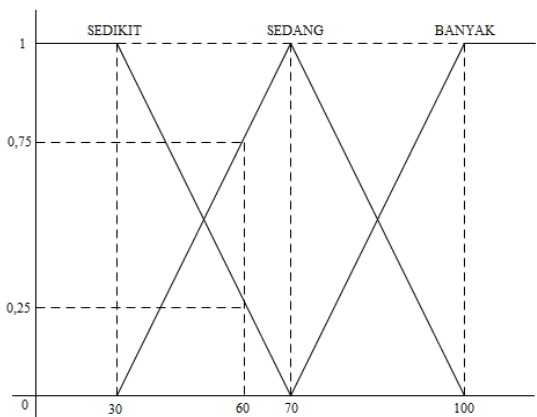

Fig. 1. Membership points

$\mu$ Few Points $[\mathrm{x}]=\{(70-\mathrm{x}) / 40$

$\mu$ Medium Points $[\mathrm{x}]=\{(\mathrm{x}-30) / 40(100-\mathrm{x}) / 30$

$\mu$ Points Many $[\mathrm{x}]=((\mathrm{x}-70) / 40$

Degree of membership grade:

$\mu$ Few Points $(60)=(70-60) / 40=0.25$

$\mu$ Medium Points $(60)=(60-30) / 40=0.75(100-60) / 30=$ 1.33

$\mu$ Many Points $(60)=(100-60) / 30=-0.33$

Time

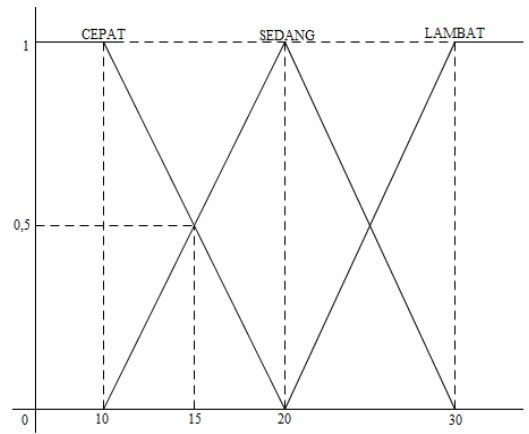

Fig. 2. Time Membership

$\mu$ Fast Time $[y]=\{(20-y) / 10$

$\mu$ Medium Time $[y]=\{(y-10) / 10(30-y) / 10$

$\mu$ Slow Time $[y]=\{(y-20) / 10$

Degree of membership value:

$(15-20) / 10=-0.5$

$\mu$ Slow Time $(15)=(30-15) / 10=1.5$

Star

$\mu$ Medium Time $(15)=(15-10) / 10=0.5$

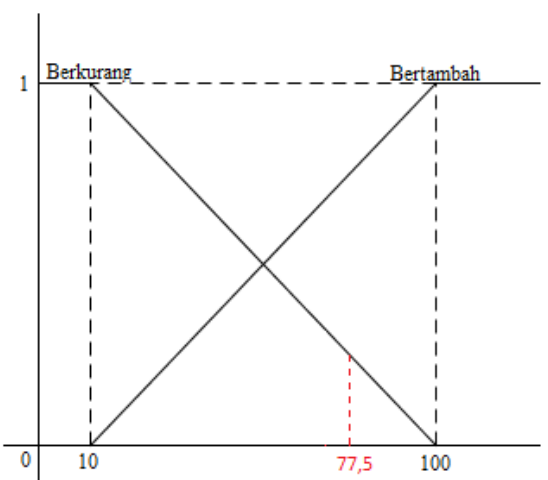

Fig. 3. Membership Star

$\mu$ Reduced Star $[\mathrm{z}]=\{(100-\mathrm{z}) / 90$

$\mu$ Increased Star $[z]=\{(\mathrm{z}-10) / 90$

Now we find the $\mathrm{z}$ value for each rule using the MIN function implication function:

$\alpha$-predicate $1=\mu$ Point Slight $\mid \mu$ Slow Time

$\alpha$-predicate $=\min (\mu$ Few Points, $\mu$ Slow Time $)$

see the set of Reduced Stars

$(100-\mathrm{z}) / 90=0.25->\mathrm{z} 1=77.5$

] IF LITTLE AND MEDIUM THEN LESSING

$\alpha$-predicate $=\min (\mu$ Low Points, $\mu$ Medium Time $)$

$\alpha$-predicate $=\min (0.25 ; 0.5)$

2.0, 25

(100-z) $/ 90=0,25->$ z2 $=77,5$

$\alpha$-predicate $=\min (0.25 ; 0.5)$

$\alpha$-predicate $3=0.25$

$(100-\mathrm{z}) / 90=0,25->\mathrm{z} 3=77,5$

[R4] IF IT IS SLOW AND SLOW THEN LESS

$\alpha$-predicate $4=0.5$

$(100-\mathrm{z}) / 90=0,5->\mathrm{z} 4=55$

[R5] IF ONLY AND ONLY ADDING

$\alpha$-predicate $5=\mu$ Medium Point $\mid \mu$ Medium Time

$\alpha$-predicate $5=\min (\mu$ Medium Points, $\mu$ Medium Time $)$

$\alpha$-predicate $5=\min (0.75 ; 0.5)$

$\alpha$-predicate $5=0.5$

see the set of Increasing Stars

$(\mathrm{z}-10) / 90=0,5$->z $5=55$ 
[R6] IF IS MEDIUM AND FAST THEN ADDED $\alpha$-predicate6 $=\mu$ Medium Points $\mid \mu$ Fast Time $\alpha$-predicate $=\min (\mu$ Medium Points, $\mu$ Fast Time $)$ $\alpha$-predicate $=\min (0.75 ; 0.5)$

$\alpha$-predicate $=0.5$

see the set of Increasing Stars

$(\mathrm{z}-10) / 90=0,5->\mathrm{z} 6=55$

[R7] IF MANY AND SLOW THEN INCREASED

$\alpha$-predicate7 $=\mu$ Many Points $\mid \mu L$ Lwn Time

$\alpha$-predicate $=\min (\mu$ Many Points, $\mu$ Slow Time $)$

$\alpha$-predicate $=\min (-0.33 ;-0.5)$

$\alpha$-predicate $=-0.5$

see the set of Increased Stars

$(\mathrm{z}-10) / 90=-0,5->\mathrm{z} 7=-35$

[R8] IF MANY AND IS THEN ADDED

$\alpha$-predicate $8=\mu$ Many Points $\mid \mu$ Medium time

$\alpha$-predicate $8=\min (\mu$ Many Points, $\mu$ Medium Time)

$\alpha$-predicate $=\min (-0.33 ; 0.5)$

$\alpha$-predicate $=0.5$ see the

set of Increased Stars

$(\mathrm{z}-10) / 90=0.5->\mathrm{z} 8=55$

$\alpha$-predicate9 $=\mu$ Many Points $\mid \mu$ Fast Time

$\alpha$-predicate $=\min (\mu$ Many Points, $\mu$ Fast Time $)$

$\alpha$-predicate $=\min (-0.33 ; 0.5)$

$\alpha$-predicate $9=0.5$ see the

set of Increased Stars $(\mathrm{z}-10) / 90=0.5->$ z9 = 55

The $Z$ value can be found in the following way:

$\mathrm{Z}=$ apred1 $* \mathrm{z} 1+\operatorname{\alpha pred} 2 * \mathrm{z} 2+\operatorname{\alpha pred} 3 * \mathrm{z} 3+\operatorname{\alpha pred} 4 * \mathrm{z} 4+$ apred5 $*$ z5 + apred6 $*$ z6 + apred7 $*$ z7 + apred8 $* z 8+$ apred $9 *$ z9 apred $4+$ apred $5+$ apred $6+\alpha$ pred $7+\alpha$ pred $8+$ apred9)

$\mathrm{Z}=0.25 * 77.5+0.25 * 77.5+0.25 * 77.5+0.55 * 55+0.55$

$* 55+0.55 * 55+(-0.55 * 55)+0.55 * 55++0.55 * 55 /(0.25$

$+0.25+0.25+0.5+0.5+0.5+(-0.5)+0.5+0.5)$

$\mathrm{Z}=19.375+19.375+19.375+27.5+27.5+27.5+17.5+$ $27.5+27.5 / 2.75$

$\mathrm{Z}=213.125 / 2.75=77.5$.

\section{System Implementation}

In the implementation and testing, the Realm 3smartphone is used pro with a screen size of 6.3 inches 1080 x 2340 pixels and uses the operating system Android 9.0 Pie. Appearance-display contained in the game education on recognizing letters hiragana and katakana can be seen as follows:

\section{Initial page display the start}

The page display displays the title game and in-game menus such as the "menusStudy", "Quiz", and "About". And a menu button that has its function where the button "Study" to start learning the game, the button "Quiz" for the entry-level menu, and button "About" to show the maker bio game.

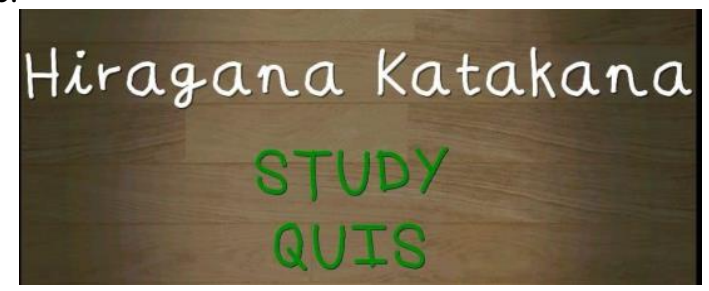

Fig. 4. Start page view
[R9] IF MANY AND FAST THEN INCREASES

Study view

In the view, there is a menu study Hiragana or study katakana which can be selected by the user and exit button to return to the initial menu, the display can be seen in Fig. 5 below.

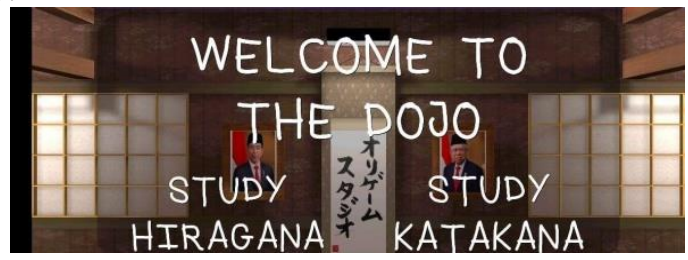

Fig. 5. Display Study

\section{Hiragana study display}

After the user selects the study Hiragana, he/she will immediately learn skills. Display study hiragana Can be seen in Fig. 6 below.

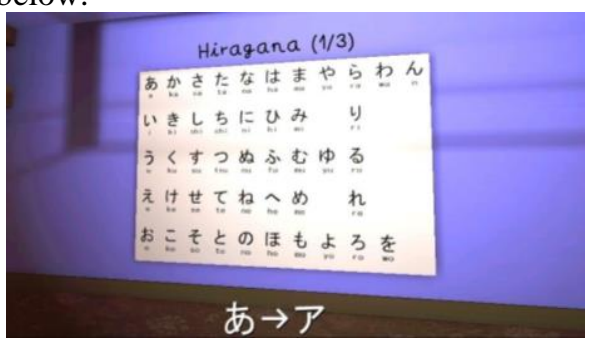

Fig. 6. Display Study Hiragana

Display Study Katakana

Once the user selects a study Katakana as well as study Hiragana appearance will immediately learn to display Study Katakana can Be seen in Fig.7 below.

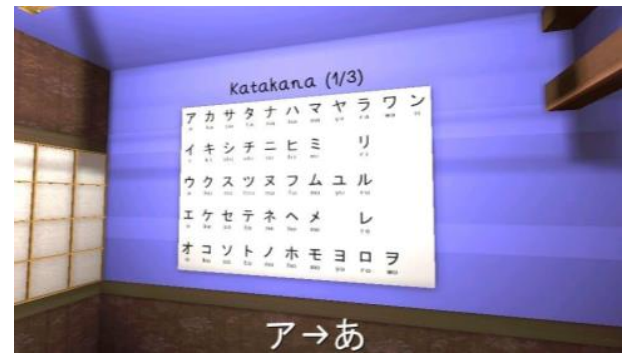

Fig. 7. DisplayStudy Katakana

\section{Display Quiz}

On view Quiz there are levels of menus that can be selected by the user to determine the level of difficulty in answering the questions, the display can be seen in Fig. 8 below.

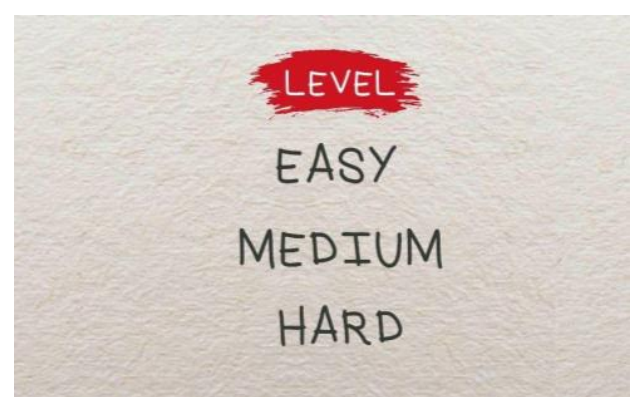

Fig. 8. Quiz Display 


\section{Display Question Page}

On the question page display the user will answer 10 questions in 30 seconds, the display can be seen in Fig. 9 below.

Time: 28
\begin{tabular}{l|l|} 
& \\
Hiragana I & \\
\hline A. ウ & B. き \\
\hline C. ソ & D. う \\
\hline
\end{tabular}

Fig. 9. Quiz Questions

\section{Page Display Results}

On the results page display the user can see how much score and time have been used in answering questions, the display can be seen in Fig. 10 below.

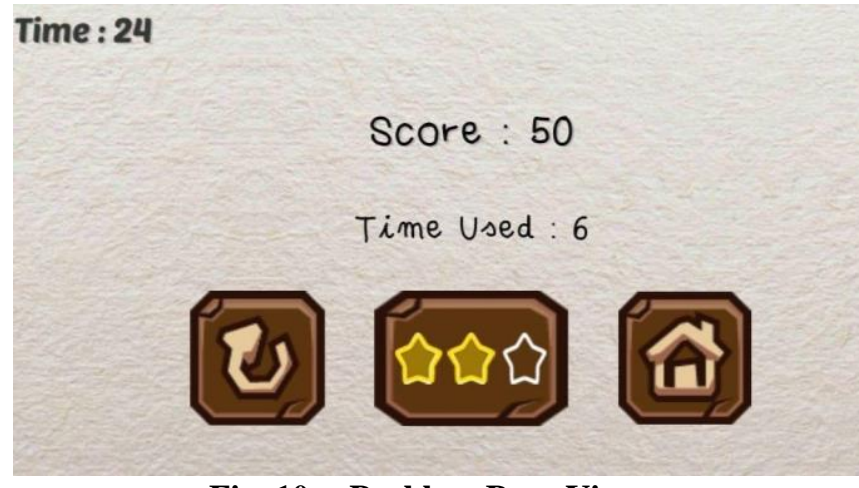

Fig. 10. Problem Page Views

\section{CONCLUSION}

After completing the analysis stage, system design, programming to the completion stage of the program in the mobile game recognizing Hiragana and Katakana letters, the following conclusions can be drawn: 1) Mobile Game recognizes Hiragana and Katakana letters. according to user requirements; 2) With the mobile game recognizing letters Hiragana and Katakana, it helps make it easier for users in the teaching and learning process and can be done anytime and anywhere; dan 3) This mobile game has successfully implemented the Algorithm FYS and Fuzzy Tsukamoto effectively. The suggestions that are expected in developing mobile games to recognize hiragana and katakana letters to make it better are as follows: 1) For further application development, it is hoped that the game not only can be played with a single player but also can be played with multiplayer; 2) For future development research, can be added databases to store player score data; 3) For future developments so that features can be added to the right or wrong in answering so that the user knows better; 4) It is hoped that further development will add actor players and non-actors player characters (NPCs).

\section{REFERENCES}

1. G.F. He, J.W. Park, S.K. Kang, and S.T. Jung. Development of gesture recognition-based serious games. In Proceedings of 2012 IEEE-EMBS
International Conference on Biomedical and Health Informatics, 2012. pp. 922-925. IEEE.

2. H. Cao, S. Lei, H. W. Deng, and Y.P. Wang, Y. P. Identification of genes for complex diseases by integrating multiple types of genomic data. In 2012 Annual International Conference of the IEEE Engineering in Medicine and Biology Society. 2012. pp. 5541-5544. IEEE.

3. I. Haditama, C. Slamet, and D. F. Rahman.(2016).“. Implementasi Algoritma Fisher-Yates dan Fuzzy Tsukamoto Dalam Game Kuis Tebak Nada Sunda Berbasis Android". JOIN, 2016. 1, 51-58.

4. M.A. Hasan, Supriadi, and Zamzami. Implementasi Algoritma Fisher-Yates Untuk Mengacak Soal Ujian Online Penerimaan Mahasiswa Baru (Studi Kasus: Universitas Lancang Kuning Riau). Jurnal Nasional Teknologi dan Sistem Informasi, 2017. 3(2), 291-298.

5. E. Ekojono, R. Cahyaningrum, and K.S. Batubulan. Implementas metode Fisher-Yates Shuffle dan Fuzzy Tsukamoto pada game 2D gopoh berbasis android. Jurnal Informatika Polinema, 2018. 4(3), 174-174.

6. Melyanti, R., Irfan, D., Ambiyar, A., Febriani, A., \& Khairana, R (2020). Rancang Bangun Sistem Antrian Online Kunjungan Pasien Rawat Jalan Pada Rumah Sakit Syafira Berbasis Web. INTECOMS Journal of Information Technology and Computer Science, 3(2), 192-198.

7. Melyanti, R. (2018). Aplikasi Pengelolaan Keberangkatan Penumpang pada PT. Indah Travel. Jurnal Ilmu Komputer, 7(1), 15-21.

8. Melyanti, R., \& Iqbal, M. (2020). Sistem Informasi Manajemen Penelitian Dan Pengabdian Masyarakat Di Bagian P3m (Studi Kasus: Stmik Hang Tuah Pekanbaru). Jurnal Ilmu Komputer, 9(2), 165-176.

\section{AUTHORS PROFILE}

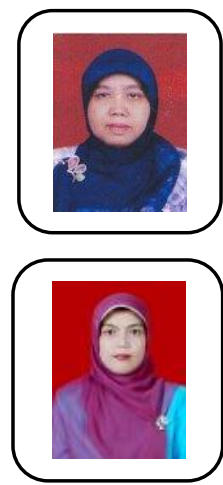

Rahmiati, is a Doctoral student of Technology and Vocational Education, Universitas Negeri Padang Indonesia and Lecturer of STMIK Amik Riau Indonesia.

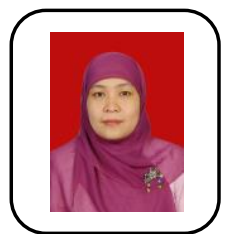

Des Suryani, is a Doctoral Student of Technology and Vocational Education, Universitas Negeri Padang Indonesia and Lecturer of UIR Riau - Indonesia.

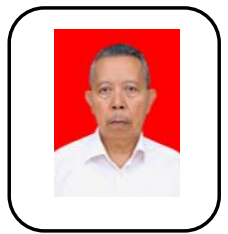

Ambiyar, is a Senior lecturers/professors of Technology and Vocational Education, Universitas Negeri Padang-Indonesia.

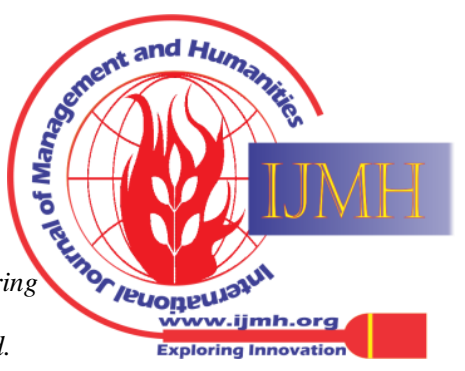

